\title{
Action research in nursing homes
}

Andersen, John; Bilfeldt, Annette

Published in:

Action Research

DOI:

10.1177/1476750315569082

\section{Publication date:}

2016

\section{Document Version}

Publisher's PDF, also known as Version of record

Citation for published version (APA):

Andersen, J., \& Bilfeldt, A. (2016). Action research in nursing homes. Action Research, 14(1), 19-35.

https://doi.org/10.1177/1476750315569082

\section{General rights}

Copyright and moral rights for the publications made accessible in the public portal are retained by the authors and/or other copyright owners and it is a condition of accessing publications that users recognise and abide by the legal requirements associated with these rights.

- Users may download and print one copy of any publication from the public portal for the purpose of private study or research.

- You may not further distribute the material or use it for any profit-making activity or commercial gain.

- You may freely distribute the URL identifying the publication in the public portal.

\section{Take down policy}

If you believe that this document breaches copyright please contact rucforsk@kb.dk providing details, and we will remove access to the work immediately and investigate your claim. 


\section{Action research in nursing homes}

John Andersen

Roskilde University, Denmark

\section{Annette Bilfeldt}

Aalborg University, Denmark
Action Research 2016, Vol. 14(I) 19-35 (C) The Author(s) 2015

Reprints and permissions: sagepub.co.uk/journalsPermissions.nav DOI: |0.I|77/|4767503|5569082 arj.sagepub.com

@SAGE

\begin{abstract}
This article concerns the experiences gained from the action research project, Quality in Elder Care, involving social dimensions of quality in public elder care. The aim of the project was to improve the professional skills and engagement of the care workers and to improve the life quality and participation of the residents. Furthermore, the idea was that the project could strengthen a public and professional discourse about more democratic and inclusive alternatives (for staff as well as residents) to the currently growing bureaucracy and expansion of top-down control systems in elder care. The project was inspired by critical utopian action research with future workshops as an important methodological tool. The project followed the core characteristics of action research to be "a shared commitment to democratic social change". The article discusses how the project contributed to changes in care quality in a joint effort between care workers, residents at the nursing home, and researchers. It concludes that the project led to empowerment of the residents and staff and played an important role in the development of democratic knowledge building about better quality and ethics in elder care.
\end{abstract}

\title{
Keywords
}

Elder care, nursing homes, empowerment, critical utopian action research, future workshop

\section{Introduction}

The action research project took place at a public nursing home in Copenhagen in 2009/10. The project followed the core characteristics of action research to be "a shared commitment to democratic social change" (Brydon-Miller, Green Wood, \& Maguire, 2003 ). The purpose of the project was the development of quality at the

\section{Corresponding author:}

John Andersen, Roskilde University, P.O. Box 260, DK-4000 Roskilde, Denmark.

Email: johna@ruc.dk 
nursing home in regard to the social needs of the residents. The project was carried out by employees and university action researchers, and financed by the trade union for public servants (FOA), as a working life project. The aim was to develop progressive alternatives to the rigid and bureaucratic forms of management that dominates the public sector in Scandinavia (Hjort, 2009; Bilfeldt, Andersen, \& Søgaard Jørgensen, 2014).

The first section outlines the roots in critical theory and sociology of the CUAR tradition, which is linked to the Paulo Freirerian concept of empowerment. The next part describes (1) how the concrete action research methodology in the project was used; (2) how the collective utopias and practical suggestions developed by the participants contributed to the development of joint social and participatory activities and; (3) how a negative spiral of disempowerment (where stressed employees were rushing about, which led to a de facto disempowerment of the residents) was substituted by the development of a human needs oriented praxis based on new social activities at the nursing home.

According to the CUAR approach the researcher has an obligation to keep a focus on ethical dilemmas and democratic interests that go beyond narrow group interests (Nielsen \& Nielsen, 2006). Working with vulnerable groups such as the elderly people (where some have cognitive impairments) requires particular awareness on ethics in the communication and daily care work with regard to the elderly people's voice, interests, and emotional expressions.

The research group had to pay special attention to asymmetrical power relations and ethical dilemmas between staff and residents throughout the lifetime of the project, for example, some employees and managers suggested restrictions (e.g. fixed bedtimes for all) vis-à-vis the elderly. In the action research process, such unethical ideas were challenged and rejected (see later). In the conclusion we discuss how the action research project became part of the development of shared democratic knowledge building about a more holistic understanding of quality in elder care (QEC).

\section{Critical utopian action research (CUAR)}

After a downturn in the 1980s and 1990s, action research has grown over the last decades in Scandinavia (Svensson \& Nielsen, 2006). At the Centre for Action Research and Democratic Social Change (http://www.ruc.dk/forskning/forskningscentre/center-for-aktionsforskning-og-demokratisk-samfundsudvikling/ om-centret/samarbejde/) at Roskilde University, a particular kind of action research, namely CUAR, has gained influence.

The distinct feature of action research is its utilization of methods that promote and develop change ideas based on everyday people's visions and experiences. The CUAR tradition has in particular been developed by the Danish action researchers, Kurt Aagaard Nielsen, Birger Steen Nielsen, and Peter Olsén (1999). They developed CUAR in the footsteps of the critical theorists Adorno and Horkheimer from the Frankfurt(er) School and in particular Kurt Lewin (1890-1947). From the authoritarian experiences of the Nazi regime, Lewin and others pointed out that 
democracy could not be taken for granted. Rather, democracy should be seen as a practice to be learned. In pioneering group experiments, Lewin developed action research as a method to frame democratic learning and acting. In the development of democratic and change-oriented knowledge, the researcher and the social actors, in cooperation, were connecting scientific knowledge to reality (Lewin, 1948; Nielsen \& Nielsen, 2006).

Other important intellectual roots of the CUAR tradition arrive from Ernst Bloch, who regarded utopian flows to be a central part of history (Bloch, 1985), from Marcuse's concept of "reality power" which emphasizes how taken for granted routines and every day practice restrict social imagination (Marcuse, 1941), and from C. Wright Mills' view on the active role of social science to frame "sociological imagination" which links "everyday troubles" (e.g. bad care for the elderly) and "societal issues" (e.g. welfare cuts and bureaucratic management at nursing homes) (Mills, 1959). In order not only to understand (and theorize like the classical Franfurter School did) reification and "reality power," but to challenge, transform, and create alternative futures, Robert Jungk developed the "Future Creating Workshop" as a practical methodology for the creation of utopian flows in democratic experimentations (Jungk \& Müllert, 1987). The future workshop has become a central tool for the development and concretization of utopian ideas in CUAR with the utopian phase as the basis of breaking away from everyday ideas of what is possible (Nielsen \& Nielsen, 2006). Following Lewin who noted: "The best way to understand things is to change them" (Lewin, 1948), the Future Creative Workshop methodology has become an important methodological tool in the Danish CUAR tradition.

CUAR is based on democratic and inclusive values where the production of knowledge contributes to collective actions. The CUAR tradition is closely connected to Paulo Freire's concept of empowerment, which he defined as the ability to "understand social, political and economic contradictions and ability to act against the oppressing elements of reality" (Freire, 1974, p. 19).

As a critical, transformative paradigm (not to be confused with neoliberal and neoconservative purely individualistic misuses of the concept, see Craig and Mayo, 1995): empowerment is defined to be a social mobilization, collective action, and social transformation. The empowerment approach has grown in the last decades, because it has opposed individualization, neoliberalism, and the market orientation which spread throughout the West during the 1980s onwards.

Andersen defines empowerment as "processes through which social groups improve their ability to create, manage and control material, social, cultural and symbolic resources"(Andersen, 2005, p. 60).

Levin has extended the definition of empowerment to:

capacity, resources, information and knowledge, confidence, understanding, organization and formal rights which humans can utilize individually and collectively to determine what is to happen to them. I also include humans' mobilization of collective visions and fantasy, intelligence, creativity, enthusiasm, courage and energy in one liberating movement. (Levin, 1995, p. 208) 
A distinction can be made between (1) horizontal empowerment that deals with strengthening networks, commitment, and trust inwards and downwards, e.g. between the different groups at the workplace and (2) vertical empowerment that deals with strengthening power and the possibilities of influence outwards and upwards, i.e. in relation to power centers outside the workplace at the macro level, including governmental policies, municipality priorities, and in relation to overall discourses and ways of governance (e.g. if the nursing home sector basically has fair conditions and is managed appropriately) (Andersen \& Siim, 2004, p. 7). Successful or robust empowerment processes are mutually strengthened over time - often developed in a mix of horizontal and vertical empowerment.

The action researcher Stephen Kemmis has emphasized the link between action research and critical theory by employing the concept of praxis which is divided between "practice" and "praxis" (Kemmis, 2008). Whereas "practice" is based on ingrained path-dependent habits and behavior (in line with Bourdieu's concept of habitus), "praxis" is the social and collective morally obliging result that can arise based on a critical/self-critical reflection and dialog in the critical action research process. One of the purposes of action research is that it reframes "practice" so that it becomes "praxis" (Kemmis, 2008).

\section{The future workshop methodology}

The Future Workshop Methodology is linked to the epistemology of CUAR. The role of the action researcher is to intervene in social and cultural processes. The researcher is both moderator and collaborator in the future workshop and, as such, has to open up for the possibility of developing democratic knowledge (Nielsen \& Nielsen, 2006).

Future workshops can be very diverse, but some of the main characteristics are:

- citizens/users/employees are the driving forces in the production of future visions, actions, and scenario building.

- "thinking outside the box" by developing utopias that are not limited by the everyday comprehension of what actually can be done.

A future workshop is organized with plenum and group sessions. The participants' statements are presented and commented upon by using posters. The researchers' role in the future workshop is to act as facilitators and referents (Jungk \& Müllert, 1987).

A future workshop has three phases (here illustrated with examples from the elder care project) (Figure 1).

The first is the critique phase which asks the question: What's wrong? What do we want to change? It involves a brainstorming session aimed at producing critical statements. All critical statements about, in this case, public eldercare were listed. These were, or instance, poor working conditions for the employees (daily stress and lack of time), life quality problems, and social isolation of the residents. 


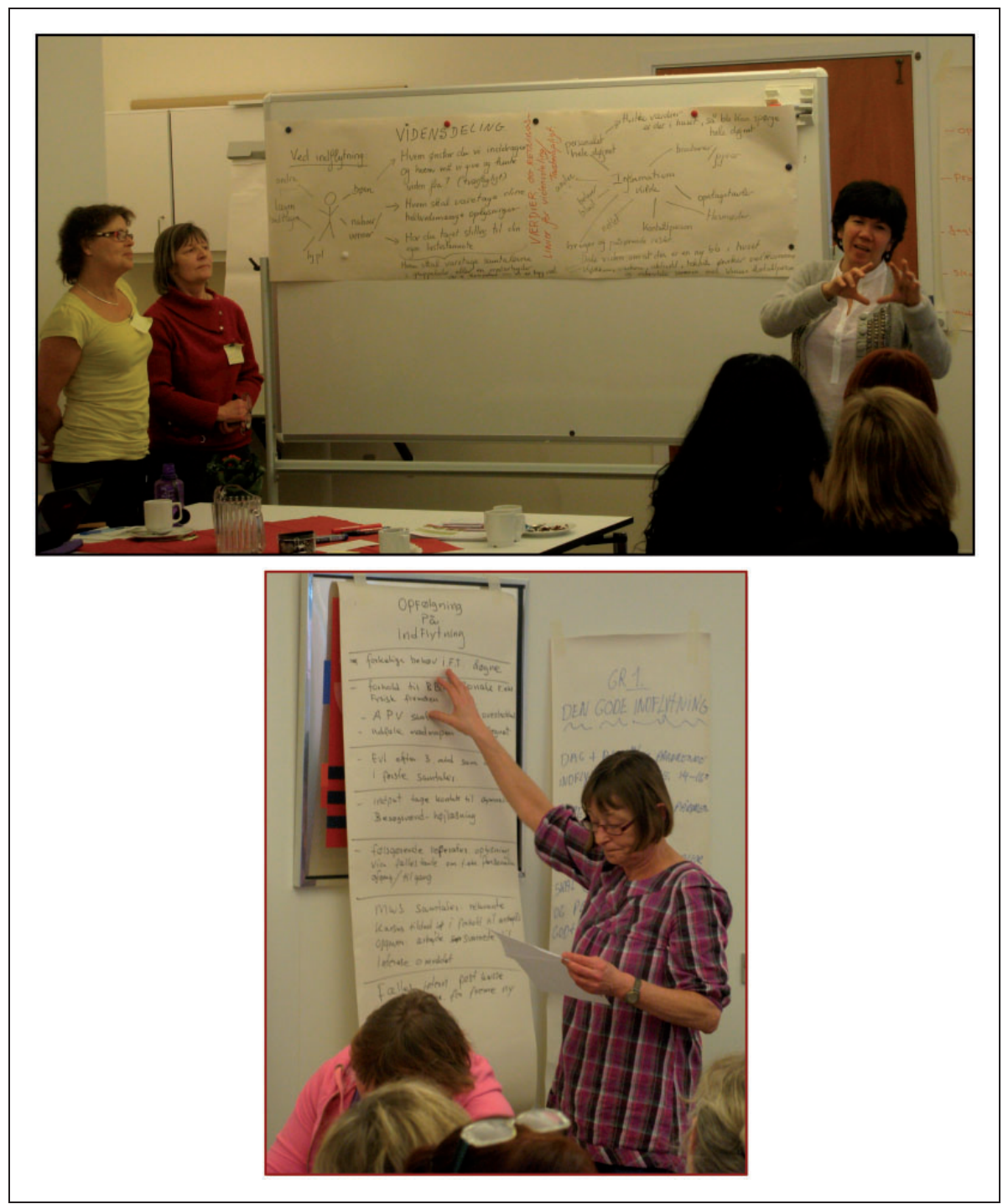

Figure I. Employees at a future workshop.

Thereafter follows the utopian phase which asks the question: Where would we like to go? The participants are asked to imagine a perfect nursing home where everything is possible (for instance more time and less stress for the employees, better life quality, and social activities for the residents). The utopian dreams and visions are listed on posters and commented on. The themes are prioritized through voting, in order to find out which utopias about the ideal nursing home and good care should be developed in utopia groups. 
Finally, the realization phase asks the question: We keep our dreams (here about QEC), but ask how can they become reality? First the participants are organized in working groups. The groups are given the task of developing the utopian ideas gained from the former phase and making them into concrete proposals. These are then critically commented upon and further developed in a plenary meeting. Second, the groups make agreements about plans for concrete implementation for the future.

The outcome is a written protocol of "utopian sketches" and a preliminary plan of action to which participants have committed themselves to work with in the future. This writing process is facilitated by the team of action researchers. Following this, additional plans for social experimentation can be developed by the employees in dialog with the residents, their relatives, other colleagues, and the manager in order to be implemented by the manager, the local authorities, and the employees.

\section{Project background}

The trade union for public service workers, FOA, financed the actions research project. With this project FOA wanted to attain a stronger voice in the public discourse about progressive alternatives to the new public management (NMP) regime, which has dominated the public sector in Denmark with increasing bureaucratic quality control systems (Bilfeldt et al., 2014).

The employees at the Copenhagen nursing home had suggested a project focusing on QEC, since they felt that they were trapped in a negative spiral of stressing, rushing and disempowering the residents. They felt that were not able to give the kind of quality in care they wanted (Andersen \& Bilfeldt, 2013). The wider context for the project was an increasing critique in the public media about neglect in elder care where employees at public nursing homes were accused of delivering inhumane treatment.

The aim of the project was to give the employees tools to develop a social response to NPM-inspired control tools. Inclusion of the residents' voices about experiences and wishes was considered crucial in order to qualify the initiatives taken.

\section{The knowledge basis of the project}

The project's research basis was Scandinavian critical care work theory focusing on the importance of showing respect to the social needs of the care receivers. Good quality in care is based on the individual understanding of those requiring care (Wærness, 2005). Narrow time schedules might lead to a daily practice without dialogs and social contact between the elderly and the employee, whereupon important knowledge about the elderly's individual needs is lacking (Bilfeldt et al., 2003). The Swedish researcher Ann Whitaker found, in a case study, that employees often develop tacit routines that dominate the individuality and 
autonomy of residents at nursing homes (avoiding paying special attention to individual needs and wishes) (Whitaker, 2009).

Recent Danish research shows that respect for the interest of the staff seems to overshadow the wishes of the elderly (Glasdam, Henriksen, Kjær, \& Praestegaard, 2013), and that residents experience lack of influence and autonomy (Bilfeldt \& Mahler, 2014).

The NPM system that has been applied to the public sector in Scandinavia allocates resources in public elder care by the way of organizing principles aimed at cost reduction. The foundation of the allocation of resources in eldercare quality is becoming increasingly organized through principles that were originally developed for industrial production. The main purpose has been the production of homogenous services which are possible to describe in a standardized way (Hjort, 2009).

Scandinavian studies in eldercare have found that when working under NPM standards, the employee might end up in a paradoxical situation where care giving is conducted through homogeneous standard descriptions instead of being conducted according to the individual needs of human beings (EliassonLappalainen \& Szebehely, 1998). Increasingly, efficiency requirements and standardization of services in detailed work descriptions lead to low priority given to the individual differences in needs and to the social dimensions of elder care (Andersen \& Bilfeldt, 2013; Eliasson-Lappalainen \& Motevasel, 1997; Szebehely, 2005; Wærness, 2005). British research indicates an urgent need for knowledge about care from the care users experience and wishes about care in order to develop the care system so that the elderly's need for autonomy can be supported (Barnes, 2006). Knowledge of the care receiver's needs is increasingly being excluded from the basis of the organization of the work (Wærness, 2005). Furthermore, Wærness points out that the professional caretaking in the Scandinavian welfare state model is reaching a "care crises" for the core values which previously were considered crucial.

\section{The methodology}

The purpose of the project was to give employees an opportunity to reflect over and improve QEC. The practical utopian outlines, which they were going to develop in future workshops were to be discussed with the residents, so their opinions, needs, and wishes could be included.

At the future creating workshop, employees have an opportunity (and a safe space) to develop concrete utopias for eldercare and to pursue their ideas and considerations in collegial teamwork in dialog with the residents. By doing this, the employees had the opportunity to develop their ideas and to try to transform them into practical solutions in the nursing home's everyday practice in dialog with management and residents of the nursing home. In the following, we provide examples of how the action research project framed the development of initiatives. 


\section{Step I: Planning the project}

The first six months were dedicated to preparing the project, planning, and fine tuning the process plan. The researchers had meetings with Union representatives, the leader of the nursing home, the shop steward, and employee representatives from the nursing home. The researchers introduced CUAR and the future creating workshop as a methodological approach to the nursing home employees and manager. From the beginning it was an important challenge to keep the focus on the integration of both the employees and residents' needs and perspectives, thus emphasizing an awareness of the elderly residents' relative lack of power. Hence there was particular concern to ensure the residents voice during the project and by involving them throughout the project, even though they were not joining the future workshop. The project also involved dialogs with relatives, elder organizations, the municipal Elder Council, experts in dementia, elder care researchers, and representatives from the union FOA.

\section{Step 2: Production of a problem catalog}

This stage involved a group interview with employees, the creation of a problem catalog, and interviews with the residents. In the group interview, the employees expressed strong feelings relating to stress and work overload. The employees also expressed that they felt trapped between the needs of the residents and scarce resources. The NPM quality standards, which were solely based on the physical abilities of the residents, were not consistent with the employees' ideas of quality. In their view, good quality ought to include having social activities with the residents or helping the residents to engage in social activities among themselves. The employees reported overwhelming fatigue by the end of the working day and expressed both anger and powerlessness concerning the work demands. In connection to the public elder policy, the "as long as possible in one's own home" policy was seen to be problematic. Residents had gotten weaker by the time of moving in to the nursing home while here were fewer employees than earlier. The employees often felt that they had to rush the residents and needed more time for social activities with the residents. They felt, for example, that they could not take care of the residents with dementia who they sometimes failed to prevent from leaving the nursing home.

The group interview was followed up by the researchers making a problem catalog where all the critical statements were summarized. After the interviewed employees had read the problem catalog, and corrected misunderstandings, the result was presented to the manager, colleagues, and residents at department meetings. At those meetings comments were given, and afterwards individual interviews with the residents were conducted by the employees. The residents said that they sat alone from the afternoons onwards, that there were no activities at the home, they did not have resources to create social activities by themselves, and they felt bored. Furthermore, the design of the building made it difficult for the residents to sit 
together. They expressed that many of them wanted to be more involved in decisions about the nursing home. They claimed that they were neither asked nor informed about changes in routines. They felt that the employees did not take time to sit down and talk for a while, and they were neither listened to nor involved in solving everyday problems at the nursing home.

The outcome was the identification of a number of problems: lack of resources, employee stress, inadequate caregiving, a lack of real dialog between the employees and the residents, the residents feeling isolated, and the residents having lack of influence on the nursing home.

\section{Step 3: The future creating workshop: From critique to action}

Step 3 consisted of the future creating workshop (the three phases in the future workshop methodology are described earlier).

When the future creating workshop started, the researchers facilitated the critique phase by summing up the problems mentioned by employees from the problem catalog and the residents' comments as a starting point.

The critique phase in the action research process opened a new communicative space by making it possible, collectively, to criticize the conditions for the care work instead of feeding feelings of personal inadequacy for the employees. Additionally, it opened a dialog with the residents about their critique and reflections about everyday life at the nursing home. The next phase in the future creating workshop was the utopian phase where a number of utopias were developed with the intent of improving the quality of care. The last phase was the realization phase. Task force groups were formed to present ideas involving the residents and the manager.

The following are examples of the output from the future workshop.

Utopia I New residents "town square". During the future workshop, an employee described a plan for the reconstruction of the nursing home with a new living room scenario which she and her coworkers had discussed with residents over several years. The future workshop made it possible for the idea to be further developed into a concrete plan of action which could be presented to the management board. The idea was that two resident rooms should be made part of the living room, close to the elevator, where the employees pass back and forth and where there are windows facing the street. The employees had dreamed of doing this for many years. The walls were to be bright and the lamps were to have a soft light. The aim was to create architectonic frames encouraging socializing among the residents and the employees. This idea was based on observations of the residents "bunching together" in the hall around the elevator, much like a town square. It was envisaged that the residents could talk to the people passing by and could greet relatives who were visiting residents. Furthermore, they could have continuous contact with the employees who, due to their work, passed the "town square" several times a day. The residents stayed at the "town square" instead of spending time in the current 
living room. Instead of relocating the residents, the living room was to be relocated. By doing this, a less institutionalized form of social interaction was promoted, strengthened by the placement of small sitting areas sheltered by palm trees and plants - all this was to encircle the elevator.

The knowledge which employees had gained through relating to residents' needs for social interaction was the foundation of the development of ideas about interior design changes.

In the realization phase of the future workshop, a task force was formed to present the idea to the management. The next step was to have the manager present the idea to the local authorities. Here the idea was well received and the plan became the foundation of a reconstruction for the building.

Decisions about the home's interior design are normally made without the employees and residents. In this project, the employees were empowered and had an influence on the home's interior design and reconstruction. The employees could point to the importance of the architectonic frames of institution life and could suggest changes that a social promoter instead of limiting the possibility of social gatherings. Rather than limiting the residents' autonomy by maintaining lamps and chairs in the current living room, which is placed far from the "town square," a plan was developed aimed at increasing social interaction. As residents who had difficulties walking were often limited to the chair in which they were placed, the idea was to change the location of the living room in an attempt to support the residents' need for social belonging, so that they could be part of social gatherings in spite of their physical challenges.

The town square idea is an example of the employees' empathy for the needs of the residents. This suggestion could only be made because the employees listened to the residents' complaints about sitting alone in the afternoon.

From the horizontal empowerment perspective (inwards), this is about employees being able to gather their knowledge from their observations about where the residents preferred to sit and transforming it into a new vision and an actual proposal for change. From the vertical empowerment perspective (upwards and outwards), it is about the proposal reaching the management and the local authorities and becoming the foundation for the reconstruction!

Utopia 2 Trip to the island of Fanø. During the future workshop, a group of employees developed a utopia about a trip to the island of Fanø with a group of residents. It was agreed that it would be hard work as several of the residents were in wheelchairs. However, it would be worth the trouble as employees would get to know the residents in a different way than within the institutional framework. Several of the employees who had worked at other homes had already been on these types of trips: "the purpose is to get them out of the routine" and to be on the same level: "when we are watching the sunset we are equals, the experience is the same for both them and us."

In the realization phase of the future workshop, a task force group was formed to present the idea to management, colleagues, and residents. Hereafter the plans 
were developed in greater detail together with the residents. The task force group of employees began, with the help of the researchers, to apply for money from different funds - without luck however. Therefore, the trip had to be dropped. The task force group decided in cooperation with the residents to arrange a "Whitsun picnic" for the residents on the home's roof terrace instead. The idea was so well received that some of the employees who had holiday joined the party without pay:

The residents were dressed in their party clothes and they waited for the door to the living room to open. Several of them were impatiently looking at their watches. Employees from the evening shift came to work earlier and in the afternoon they decorated the living room with flowers. The tables were covered with napkins folded in glasses and candles were ready to be lit.... If we had not had the chance to dream of Fanø, all of this would have never happened. It was definitely worth it. (Nursing home employee)

A Whitsun picnic was arranged on residents' respective floors for those who were unable to take the elevator to the fourth floor (such as those suffering from dementia). Thus, attention to individual residents' needs played a central role in the plan.

The motivation behind the trip to the island of Fanø was a wish to strengthen relations by temporarily erasing the care giver-care receiver relation and a wish to gain increased knowledge about the residents as human beings. There were several suggestions concerning the development of the residents' resources, e.g. at trip to Tivoli which would involve the participation of the employees' family members in order to be able to handle all the wheelchairs and walkers. The employees expressed joy at seeing the residents increased independence when outside of their everyday institutional frames: "In Tivoli they can eat a large plate of food without help!'” One employee's adult daughter went and helped and the husband of one of the employees, who was not present, used his "Gold Card" (that is admission tickets), so that some of the residents could be admitted without having to pay.

Another suggestion was a utopia about the establishment of a café with a kiosk at the nursing home. The idea was to get the residents to socialize more after 3 p.m. when the day duty ended. The residents were to have a place to meet in the afternoon. A mobile kiosk was to roll around the nursing home as a "social link" to shops outside the nursing home for residents who could not walk. Thereby, the fussy routines for buying goods were broken. It was no longer necessary to order a magazine weeks in advance.

\section{From practice to praxis}

The project was organized in order to integrate the residents' responses to utopias and action suggestions as a direct part of the process. The interviews showed that residents felt that there was too little time for talking with the employees, that the residents wanted the employees to take their time and converse, and that they 
wanted to get more involved in decision making at the nursing home. The employees became more aware of the importance of taking time to sit down and talk with the residents for a while. The new living room opened the possibility for a new praxis by framing an informal dialog between employees and residents.

Since the residents had said that they wanted to be more involved in decisions about the nursing home, the manager decided to let the residents be represented at the staff recruiting meetings. This turned out to be a success because the residents looked for other qualities than did the employees and the manager. For the residents it was important that the care worker was polite (shook hands and maintained eye contact with the residents during the meeting) and was genuinely interested in the residents.

Following the residents' critique about lack of involvement in decision making, a decision was made to hold monthly meetings at each department about everyday problems. One of the first problems to be solved was that of preventing residents with dementia from leaving the nursing home. Other residents suggested covering the lift button with a piece of paper, because they had noticed that residents with dementia could not work out how to press the lift button if it was covered by a piece of paper (only residents without dementia joined the meetings). Other everyday problems were solved by residents informing the employees about their observations about the needs of the weakest residents. It turned out that the residents had valuable knowledge about other residents that the employees did not have, for instance that if a coffee cup was placed too far from the weak residents, most of them did not drink the coffee, and if meat was not cut into small pieces they did not eat it. And as dirty dishes were gathered by other employees later (students who only had to gather dirty dishes) neither the staff nor the manager knew about this problem until it was mentioned by the other residents.

By framing social life among the residents and involvement of residents in decision making, an empowerment process had been started. In line with Kemmis' concept of "praxis," important steps to a more social and collective morally obligatory praxis had been taken. The new praxis led to empowerment in a twofold manner focused on the well-being of the residents as well as increased job satisfaction of the employees due to the changes.

\section{Ethical challenges}

A precondition for action research living up to the hope of research and practice enriching each other is that special consideration is paid to ethical challenges (Brydon-Miller, 2008). As Brydon-Miller points out "too often the role of power is overlooked in contexts of action research" (Brydon-Miller, 2008, p. 207). In particular, she further underlines the importance of "examining the ethical challenges involved in doing research in settings of highly unequal power" (BrydonMiller, 2008, p. 207). It was important to create spaces for learning and for the development of visions and actions with awareness of the power balance between staff and residents. However positive the intentions of the employees might be, 
there was a risk of developing change initiatives that the residents had no interest in or that were not in their interest (Holmgren et al., 2013). Special awareness has to be shown to the democratic obligations connected to action research in elder care because of the power difference between the employees and the elderly. Elder care research has documented that employees are likely to overlook the importance of the elderly being involved in decisions, and that they are likely to make fragmentary solutions that may not be in the interest of the residents (Andersen, Bilfeldt, \& Søgaard Jørgensen, 2014; High \& Rowles, 1995). For that reason the residents were interviewed during the project and informed, involved, and asked about their opinions.

A few of the spontaneous "utopias" put forward by employees turned out to be "dystopias" implying restrictions that did not address the needs of the residents (making restrictions instead of strengthening the autonomy of the residents). One example was the suggestion that residents be in bed by half past eight o'clock in order to save time for the night shift. Such ideas were criticized in the workshops. One of the particular strengths of the participatory process was the way in which such undemocratic - or unethical - ideas were articulated and, after open discussion, eliminated.

As Gaventa and Cornwell (2008) suggest, even though the participatory method of action research enhances democratic knowledge development, pitfalls exist.

\section{Conclusion and perspectives}

A strong rationale for action research designs is that such participatory research designs can overcome "research fatigue," which many researchers and consultants face when they enter work places. Skepticism can be overcome because the action research design is focused on giving the involved actors ownership of both the process and the results of the project.

To sum up the strengths of the action research project, it "collectivized" frustration and critique at the workplace. Further, it made it possible for the employees and the residents to articulate and develop visions for alternatives. In this way, a change process was initiated (see Figure 2). When dialog, reflections, and collective development of knowledge of care between employees and residents became the beginning of a new praxis, the contours of an alternative strategy to the NPM agenda of standardization of care service were developed. In a research perspective, action research gave practice-related contributions to the critical societal diagnosis of the public eldercare sector.

With regard to lessons for action research, while working with citizens considered to be vulnerable, we learned that

1. The voice of the elderly themselves could and should be directly incorporated from beginning to end in the project (Brydon-Miller, 2008). The starting point of this project was to work with the staff, but supplemented by including the elderly. In future research we strongly recommend an approach with a double and 


\begin{tabular}{|c|c|}
\hline $\begin{array}{l}\text { Objectives of the } \\
\text { project }\end{array}$ & $\begin{array}{l}\text { Improved engagement of staff and quality in elder care. Demo cratic and } \\
\text { participatory alternatives to bureaucratic management }\end{array}$ \\
\hline $\begin{array}{l}\text { Context of the } \\
\text { project }\end{array}$ & $\begin{array}{l}\text { Negative public discourse, negative image of careworkers. Stress among staff. } \\
\text { Disempowerment of residents. } \\
\text { Increasing bureaucratic control regime (New Public Managemen t) }\end{array}$ \\
\hline $\begin{array}{l}\text { Roles of the action } \\
\text { researchers }\end{array}$ & $\begin{array}{l}\text { Facilitate and frame the process of change. } \\
\text { Focus on ethical and democratic dilemmas }\end{array}$ \\
\hline $\begin{array}{l}\text { Central processes } \\
\text { and methods }\end{array}$ & $\begin{array}{l}\text { Group interviews facilitating problem identification. Future creating workshop } \\
\text { facilitating visions and concrete alternatives. }\end{array}$ \\
\hline Challenges & $\begin{array}{l}\text { Ethical challenges about the risk of overlooking power structures between } \\
\text { management, employees and residents. }\end{array}$ \\
\hline $\begin{array}{l}\text { What results were } \\
\text { achieved? }\end{array}$ & $\begin{array}{l}\text { Empowerment of the residents and higher job satisfaction for the employees. } \\
\text { Dialogue, reflections and collective development of knowledge of care } \\
\text { between employees and residents. The beginning of a new praxis, contours of } \\
\text { an alternative strategy to the NPM agenda of standardization of care service. }\end{array}$ \\
\hline
\end{tabular}

Figure 2. Objectives, methods and results of the action research project.

parallel perspective. Resident and staff perspectives should be treated as equal during the action research process. Additionally, the interest of the residents should be kept in focus as the most central due to their more vulnerable and dependent position. We have paid particular attention to the important task of determining the opinion of weaker residents. By way of small interviews on selected themes, with residents who were unable to join the future workshop, we found that the (relatively) resourceful residents were able to express the needs of the (relatively) weaker (e.g. residents suffering from dementia).

This is in line with the elder care researcher, Marian Barnes, who generates essential knowledge about care from participatory research with eldercare users (Barnes, 2006).

2. In a later (ongoing) action research project, we have developed stronger direct involvement of the elderly more systematically (removed for reviewer). The striking results provide important knowledge about violation of the autonomy of fragile elderly in everyday life at nursing homes. For example:

- Interrupting the elderly watching a film on television in the evening in order to get them to bed early.

- Moving a person's wheelchair so that they have to be separated/sit away from friends they prefer to sit with at lunch time.

- Walking into a person's flat/room without knocking. 
- Speaking rudely to a resident's family if they express their dissatisfaction/ critique of something.

One final perspective which relates to the vertical dimension of empowerment processes (see above) is how to move from a local level to higher level in society.

A central challenge is to focus on creating forums and mechanism. Another challenge is to spread and consolidate knowledge and experiences outside the individual work place. It is important, therefore, that researchers, unions, and progressive managers facilitate a more systematic link between, on the one hand: capacity building and development of good local practice, and on the other hand, a societal perspective for transforming the contemporary policy agenda.

\section{Acknowledgement}

We thank Hilary Bradbury for leading the review process of this article. Should there be any comments/reactions you wish to share, please bring them to the interactive portion (Reader Responses column) of the website: http://arj.sagepub.com.

\section{Declaration of Conflicting Interests}

The author(s) declared no potential conflicts of interest with respect to the research, authorship, and/or publication of this article.

\section{Funding}

The author(s) received no financial support for the research, authorship, and/or publication of this article.

\section{References}

Andersen, J., \& Bilfeldt, A. (2013). Social innovation in public elder care: The role of action research. In F. Moulaert, D. MacCallum, A. Mehmood, \& A. Hamdouch (Eds.), The International Handbook On Social Innovation: Collective Action, Social Learning and Transdisciplinary Research (Vol. 1, pp. 320-332). Chapter 24. Massachusets USA: Edward Elgar Publishing, Incorporated.

Andersen, J., Bilfeldt, A., \& Søgaard Jørgensen, M. (2012). Det urbane plejehjem: empowermentplanlægning i praksis. In J. Andersen, et al (Eds), Byen i bevagelse: mobilitet - politik - performativitet (pp. 96-115). Frederiksberg: Roskilde Universitetsforlag.

Andersen, J., Bilfeldt, A., \& Jørgensen, M. S. (2014). Action research and empowerment in Denmark: Experiences from three different contexts. In Marianne Kristensen, \& Jørgen Bloch Poulsen (Eds.) Participation and Power (pp. 99-122). Denmark: Aalborg University.

Andersen, J., \& Siim, B. (Eds.) (2004). Politics of inclusion and empowerment: gender, class and citizenship. Houndmills, New York, NY: Palgrave Macmillan.

Barnes, M. (2006). Having a say in care/care full deliberation: older people participating in decision making. Retrieved from https://sparc.tcd.ie/newsAndEvents/conf2010\%20 Marian_Barnes\%20for\%20website.pdf

Bilfeldt, A., Andersen, J., \& Søgaard Jørgensen, M. (2014). Action research and empowerment in Denmark - experiments from three different contexts. In J. Bloch Poulsen, \& 
M. Kristiansen (Eds.), Participation and power. In participatory action research. Denmark: Aalborg Universitetsforlag.

Bilfeldt, A., \& Mahler, M. (2014). Action research in elder care - giving voice to residents and their relatives at nursing homes: a democratic alternative to the new public management? Denmark: Aalborg University Working paper.

Bilfeldt, A., Hofmeister, E., Søgaard Jørgensen, M., Meyer-Johansen, H., \& Stauning, I. (2003). A good work: quality and values in the job. In H. Hvid, \& P. Hasle (Eds.), Human resources at work (pp. 107-143). London, UK: Ashgate.

Bloch, E. (1985). Das Prinzip Hoffnung: In Fünf Teilen. Wissenschaft, Frankfurt a., Germany: M. Suhrkamp.

Brydon-Miller, M. (2008). Ethics and action research: deepening our commitment to principles of social justice and redefining systems of democratic practice. In P. Reason, \& H. Bradbury (Eds.), The Sage handbook of action research: participative inquiry and practice (2nd ed., pp. 199-210). London, UK: Sage Publications.

Brydon-Miller, M., Greenwood, D., \& Maguire, P. (2003). Why action research? Action Research, 1, 9-28.

Craig, G., \& Mayo, M. (1995). Community participation and empowerment: the human face of structural adjustment or tools for democratic transformation? In G. Craig, \& M. Mayo (Eds.), Community empowerment: a reader in participation and development (pp. 1-11). London, UK, New Jersey: ZED Books.

Eliasson-Lappalainen, R., \& Motevasel, I. N. (1997). Ethics of care and social policy. Scandinavian Journal of Social Welfare, 6, 189-196.

Eliasson-Lappalainen, R., \& Szebehely, M. (1998). Omsorgskvalitet i svensk hemtjänst: Hotad eller säkrad av att mätas? In R. Eliasson-Lappalainen, \& M. Szebehely (Eds.), Vad förgår och vad består? En antologi om äldreomsorg, kvinnosyn och socialpolitik (pp. 124-159). Sweden, Lund: Arkiv förlag.

Freire, P. (1974). Pedagogy of the oppressed. New York, NY: Continuum.

Gaventa, J., \& Cornwall, A. (2008). Power and knowledge. In P. Reason, \& H. Bradbury (Eds.), The Sage handbook of action research: participative inquiry and practice (2nd ed., pp. 121-137). London, UK: Sage Publications.

Glasdam, S., Henriksen, N., Kjær, L., \& Praestegaard, J. (2013). Client involvement in home care practice: a relational sociological perspective. Nursing Inquiry, 20, 329-340.

High, D. M., \& Rowles, G. D. (1995). Nursing homes residents, families and decision making: toward a theory of progressive surrogacy. Journal of Aging Studies, 9, 101-117.

Hjort, K. (2009). Competence and development in the public sector: development or dismantling of professionalism? In K. Illeris (Ed.), International perspectives on competence development: developing skills and capabilities (pp. 112-124). London, UK; New York, NY: Routledge.

Holmgren, J., Emami, A., Eriksson, L. E., \& Eriksson, H. (2013). Intersectional perspectives on family involvement in nursing home care: rethinking relatives' position as a betweenship. Nursing Inquiry, 21, 227-237.

Jungk, R., \& Müllert, N. (1987). Future workshops: how to create desirable futures. London, UK: Institute for Social Beyond Democracy Inventions.

Kemmis, S. (2008). Critical theory and participatory action research. In P. Reason, \& H. Bradbury (Eds.), The Sage handbook of action research: participative inquiry and practice (2nd ed., pp. 21-138). London, UK: Sage Publications. 
Levin, R. (1995). The politics of empowerment. In A. Callari, S. Cullenberg, \& C. Biewener (Eds.), Marxism in the postmodern age: confronting the new world order (pp. 208-217). New York, NY: The Guilford Press.

Lewin, K. (1948/1997). Action research and minority problems. In K. Lewin (Ed.), Resolving social conflicts: field theory in social science (pp. 143-152). Washington, DC: American Psychological Association.

Marcuse, H. (1941). Some social implications of Modern Technology. Studies in Philosophy and Social Science, 9, 414-439.

Nielsen, K. Aa., \& Nielsen, B. S. (2006). Methodologies in action research. In K. Aa. Nielsen, \& L. Svensson (Eds.), Action and interactive research: beyond practice and theory (pp. 63-88). Maastricht, The Netherlands: Shaker Publishing.

Nielsen, K. Aa., Nielsen, B. S., \& Olsén, P. (1999). Demokrati som lareproces. Denmark, Frederiksberg: Roskilde Universitetsforlag.

Svensson, L., \& Nielsen, K. Aa. (2006). Action research and interactive research. In K. Aa. Nielsen, \& L. Svensson (Eds.), Action and interactive research: beyond practice and theory (pp. 63-88). Maastricht, The Netherlands: Shaker Publishing.

Szebehely, M. (2005). Care as employment and welfare provision: child and elder care in Sweden at the dawn of the 21 st century. In H. M. Dahl, \& T. R. Eriksen (Eds.), Dilemmas of care in the Nordic welfare state: continuity and change (pp. 80-97). Aldershot, UK: Ashgate.

Wærness, K. (2005). Social research, political theory and the ethics of care in a global perspective. In H. M. Dahl, \& T. R. Eriksen (Eds.), Dilemmas of care in the Nordic welfare state: continuity and change (pp. 15-30). Aldershot, UK: Ashgate.

Whitaker, A. (2009). Family involvement in the institutional eldercare context. Towards a new understanding. Journal of Aging Studies, 23, 158-167.

\section{Author biographies}

John Andersen, PhD in Sociology, is a Professor at Department of Environment, Social and Spatial Change, Roskilde University, Denmark. Since the nineties, he has worked with action research and facilitation of community empowerment in urban areas. In recent years, he has been active in critical planning studies in Denmark.

Annette Bilfeldt, PhD in Social Science, is an Associate Professor in social innovation at the Department of Learning and Philosophy, Aalborg University, Denmark. Since the nineties, her field of research has been participatory action research in public welfare institutions, social innovation and empowerment. Her research has focus on democratic transformations of public elder care. 